Article

\title{
Classification of Landscape Physiognomies in Rural Poland: The Case of the Municipality of Cekcyn
}

\author{
Anna Górka ${ }^{1, *}$ and Kazimierz Niecikowski ${ }^{2}$ \\ ${ }^{1}$ Faculty of Architecture, Gdańsk University of Technology, Poland; E-Mail: anna.gorka@pg.edu.pl \\ ${ }^{2}$ Faculty of Oceanography and Geography, University of Gdańsk, Poland; E-Mail: kazimierz.niecikowski@ug.edu.pl \\ * Corresponding author
}

Submitted: 15 April 2021 | Accepted: 7 June 2021 | Published: 14 October 2021

\begin{abstract}
This article presents a methodology and the results of the classification of the rural landscapes physiognomies conducted on the study area located in the municipality of Cekcyn, Poland. The study aimed to develop a landscape identification method that would combine natural, cultural, and visual criteria with which to implement the provisions of the European Landscape Convention. The realization of the European Landscape Convention in Poland is incomplete due to the lack of practical application of landscape assessment in land management and spatial planning at the commune level. The research was intended at helping to fill this void. The study develops a method using which it will be possible to protect the diversity and beauty of Europe's rural landscapes more effectively. The goal has so far been of little scientific interest in Poland. The physiognomy of the studied area was analyzed with the use of commonly available spatial data and by means of field studies. Physical-geographical units and cultural characteristics have been designated based on spatial databases. Landscape patterns were identified by analyzing visual fields with the use of both GIS applications and field studies. This practice made it possible to determine physiognomic units of the landscape which are internally coherent and relatively homogeneous in terms of physical-geographical, cultural, and visual features. Identifying the landscape physiognomy within the designated landscape physiognomic units serves to harmonize spatial alterations in the area of rural communes in processes of land management and planning.
\end{abstract}

\section{Keywords}

land management; landscape assessment; landscape physiognomy; Poland; rural areas

Issue

This article is part of the issue "Towards Green(er) Cities: Contextualizing Green Benefits for Urban Spaces and Contemporary Societies" edited by Juaneé Cilliers (University of Technology Sydney, Australia).

(C) 2021 by the authors; licensee Cogitatio (Lisbon, Portugal). This article is licensed under a Creative Commons Attribution 4.0 International License (CC BY).

\section{Introduction}

The European Landscape Convention (hereafter referred to as ELC, the international convention signed by the parties in Florence, 2000, ratified in Poland in 2005) shifted the focus from landscape protection to landscape management of identified areas. Primarily, the visual aspect of landscape represents its natural and cultural phenomena (Bell, 2012). Its recognition provides a prerequisite to harmonizing natural and social processes and to support spatial decision-making. The visual landscape assessment assumes an active human role in shaping the space. For this reason, the inclusion of visual landscape assessment in management and planning procedures is closely related to maintaining spatial order (Antunes et al., 2009; Bishop \& Phillips, 2012; Özesmi \& Özesmi, 2004). This statement is confirmed by the systemic functioning of landscape assessment methods applied in the spatial planning of many European countries and worldwide (e.g., Cherrie, 2007; Fairhurst, 2004; Natural England \& Department for Environment, Food \& Rural Affairs, 2014; Tudor, 2014; Wascher, 2005). The present 
article aimed to develop and test a methodology for visual landscape assessment in line with the holistic approach proposed in the ELC to be directly applied in spatial planning of rural municipalities in Poland. The study refers to the concept of landscape as physiognomy of an area, popularized in Poland (Bogdanowski, 1999; Bogdanowski et al., 1981, p. 8; Chmielewski et al., 2017, 2019), and merges map-based and aesthetic methods used by Polish researchers separately within the disciplines of physical geography (e.g., Chmielewski et al., 2014; Sowińska \& Chmielewski, 2008), as well as within architecture and urban planning (e.g., Forczek-Brataniec, 2018; Myczkowski et al., 1998).

Each area has its character formed by physical shapes and their arrangement identified depending on people's associations and memories. For this research, landscape physiognomy was defined as a spatial pattern, specific and relatively stable, which is possible for an observer to recognize. The spatial pattern provides a dynamic composition created by a unique structure of elements, as well as natural and/or cultural features, such as geological formations, landform, settlements, forms of greenery, or types of land use and development (Antrop, 2000; Novák, 1950/1997). People who experience the patterns can read them and use them "as a guide for landscape restoration" (Bell, 2012, p. 13). The adopted extensive landscape composition arises as to the visual motifs from the viewpoints located on the designated routes (Appleyard et al., 1964; Bogdanowski, 1976, 1999; Forczek-Brataniec, 2008) and of images (Cullen, 1961, pp. 17-19). The perceived composition is a kind of mental, three-dimensional model of the arrangement of landscape elements and their features; or a kind of holistic concept of the landscape structure (Kaplan et al., 1998, p. 18); or a "landscape scenario" (Böhm, 2016, p. 286). The perceived composition depends on the availability of observations or viewpoint connections from scenic routes. The consideration of the perceived spatial composition in the process of landscape patterns identification allows for a relative agreement between the visual experiences of observers and the results of landscape classification based on physical, measurable factors to be obtained.

The perceived landscape is an integral phenomenon, but the analysis of its physiognomy can be done by a functional examination of the separate layers of factors as follows:

- A layer of natural characteristics, which consists of biotic and abiotic natural resources (Chmielewski et al., 2015; Richling \& Ostaszewska, 2005), such as geology, soils, relief, water, and vegetation. These resources provide a genetic skeleton of the current landscape;

- A layer of cultural characteristics, which consists of the elements and features of any anthropogenically transformed natural cover and cultural cover (Bogdanowski et al., 1981). Contemporary land use and its historical variability are examined within this layer of analysis;

- A layer of visual characteristics, which defines the accessibility of the views, aspects of landscape exposure, and the spatial composition of the area (Bogdanowski, 1976; Böhm, 2016). Within this layer of analysis, it becomes possible to explain how the material attributes of the landscape, both natural and cultural, become apparent to the observer (Litton \& Tetlow, 1978, p. 52; Smardon et al., 1986, p. 159; Tetlow \& Sheppard, 1979, pp. 117-124).

The comparison of physical, geographical, and cultural characteristics, along with the perceived exposure and spatial composition, leads to the determination of somewhat internally homogeneous areas called "landscape physiognomic units" (LPUs).

\section{Materials and Methodology}

\subsection{The Scheme of LPUs' Identification Process}

The LPUs' identification process is presented in the block diagram in Figure 1.

\subsection{The Study Area}

The study was conducted in the Kuyavian-Pomeranian Voivodeship, namely in the Cekcyn municipality, whose area totals $253.3 \mathrm{~km}^{2}$. The research area of $36.7 \mathrm{~km}^{2}$ is located in the west part of the Cekcyn municipality, almost entirely on the Świecie Upland (mesoregion serial no. 314.73 in the classification system by Solon et al., 2018), next to the Brda Valley mesoregion (no. 314.72) towards the west, and within the Tuchola Forest mesoregion (no. 314.71) towards the north and north-east. The municipality recognized it as a homogeneous settlement and agricultural zone in the Study of Spatial Development Conditions and Directions (Cekcyn Municipality Council, 2018). The area is covered by a mosaic of fields, forests, settlements, and lakes (the percentage of land cover areas equal $24.8 \%, 6.75 \%, 1.8 \%$, and $2.2 \%$, respectively).

The area adopted for research is fully covered by nature and landscape protection programs, represented by the Tuchola Landscape Park, its buffer zone protection plan, and the Śliwice Protected Landscape Area. These protection measures cover $70 \%$ and $30 \%$ of the study area, respectively, while local plans only apply to $2.5 \%$ of the total area.

\subsection{Desk Study}

Cartographic studies included the natural and cultural landscape factors of the examined area and the fields of visibility. A dozen or so auxiliary maps were made (Table 1), which were used to identify the following auxiliary areas: 


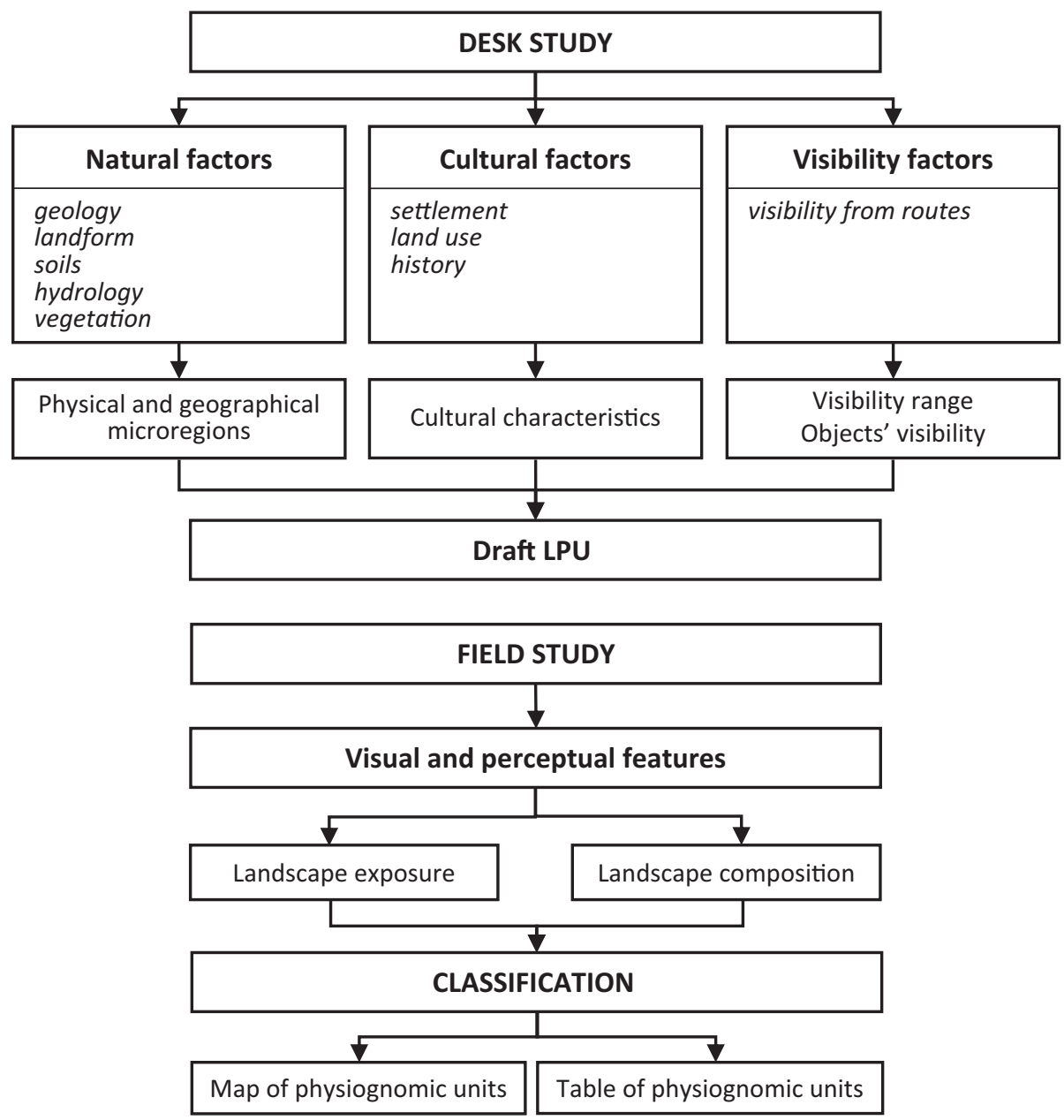

Figure 1. Methodology of identification of LPUs.

- Physical-geographical microregions: Polish geographers designate them as the most minor basic physical-geographical units: areas of similar genesis and geological structure, soil types, and landforms. They partly correspond to landscape units in the English-language research tradition, which are consistent in their topography, geology, and land cover. Physical-geographical units were determined by means of the guiding factors terrain and geological structure. Their initial outline was determined by analyzing hypsometric, geomorphological, and water surface maps (Table 1, no. 1-3). Then, fragments of boundaries characterized with an uncertain sequence were detailed based on an orthophoto map and maps which present such factors as plants cover or soil fertility of the area (Table 3, no. 4-7);

- Cultural characteristics: areas with relatively homogeneous land use and land cover, along with the history of their transformation. They were determined following the analysis of archival and modern cartographic sources. The variability was assessed by comparing past and contemporary shapes of fields and homestead locations (Table 1, no. 13). The types and distribution of cover ele- ments and features were analyzed considering the types of their usage: forests, mowed and overgrown meadows, and developed areas (Table 1, no. 8), fields surface patterns (Table 3 , no. 14), development types (Table 1, no. 15), and the antiquity of the units (Table 1, no. 11-12);

- Fields of visibility were determined based on computer modeling of viewshed from the essential local roads. A set of analyses into horizon and viewing plan was prepared for all bicycle routes in the study area. The surface sizes of areas visible from bicycle routes and other roads selected for the studied area were compared (Table 1, no. 17-18). Moreover, the analysis of the visibility range from the church tower in Cekcyn was also made (Table 1, no. 19). Insubstantial walls of the landscape rooms were indicated, along with well-exposed elements and areas. The results of computer modeling of viewshed were used for subsequent field studies of landscape exposure and composition.

The analytical units are shown in Figures 2 and 3. A full description of the desk study tools and measurements is listed in Table 1. 


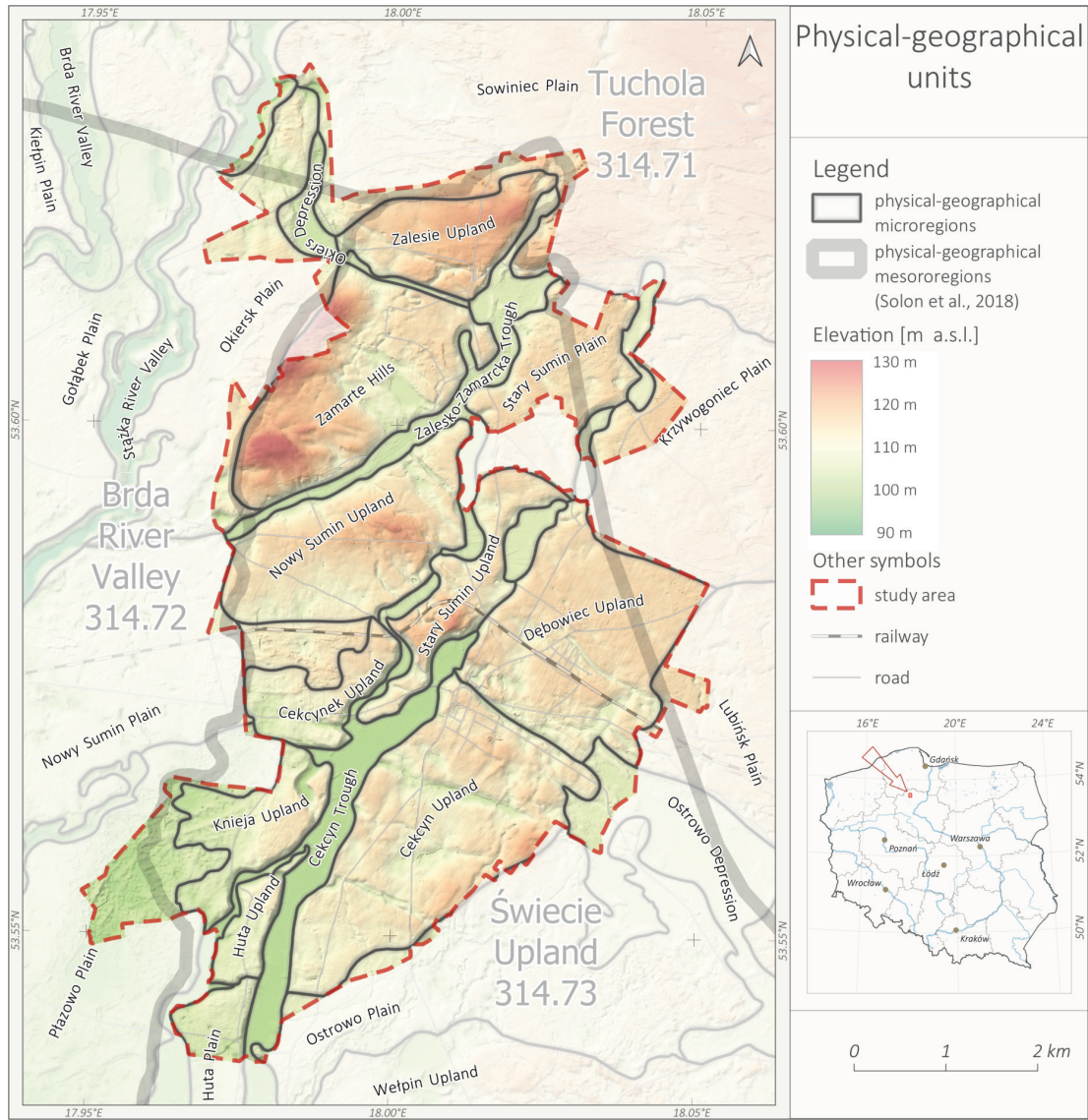

Figure 2. Designated physical-geographical units in the study area.

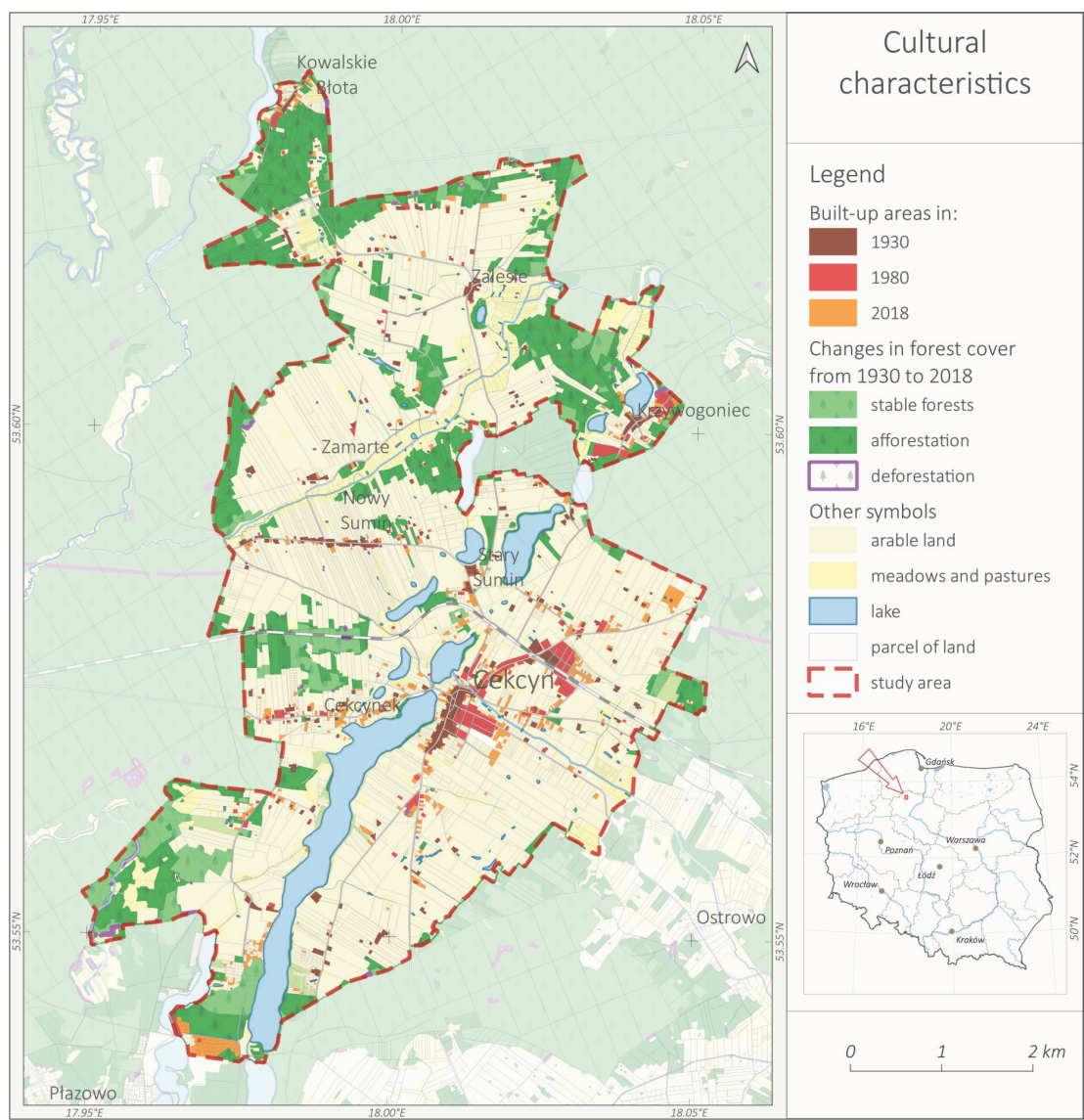

Figure 3. Designated cultural characteristics in the study area. 
Table 1. List of prepared auxiliary maps.

\begin{tabular}{|c|c|c|c|c|}
\hline No. & Title & $\begin{array}{l}\text { Type of } \\
\text { factors }\end{array}$ & Data source & Methods/comments \\
\hline 1 & Surface Waters & \multirow{7}{*}{ 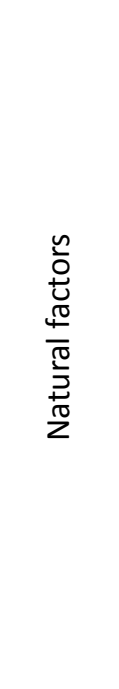 } & $\begin{array}{l}\text { DoTO10k, } \\
\text { ORTHO }\end{array}$ & $\begin{array}{l}\text { The separation of surface waters on DoTO10k was updated } \\
\text { based on the orthophoto map. }\end{array}$ \\
\hline 2 & Hypsometry & & $\begin{array}{l}\text { DTM, DoTO10k, } \\
\text { LaBR }\end{array}$ & $\begin{array}{l}\text { A translucent shading layer was applied to the hypsometry } \\
\text { to enhance the relief. }\end{array}$ \\
\hline 3 & Orthophoto Map & & ORTHO, LaBR & \\
\hline 4 & Plant Cover & & $\begin{array}{l}\text { ORTHO, } \\
\text { DoTO10k, LaBR }\end{array}$ & $\begin{array}{l}\text { Separation of plant cover based on DoTO10k and LaBR land } \\
\text { use contours are detailed based on the orthophoto map. }\end{array}$ \\
\hline 5 & Geomorphology & & $\begin{array}{l}\text { DGMP50k, } \\
\text { DoTO10k, LaBR }\end{array}$ & \\
\hline 6 & Soil Fertility & & LaBR, DoTO10k & $\begin{array}{l}\text { Soil fertility on agricultural land according to LaBR } \\
\text { bonitation classes. }\end{array}$ \\
\hline 7 & $\begin{array}{l}\text { Physical and } \\
\text { Geographical } \\
\text { Microregions }\end{array}$ & & $\begin{array}{l}\text { DGMP50k, } \\
\text { DTM, ORTHO, } \\
\text { DoTO10k, LaBR }\end{array}$ & $\begin{array}{l}\text { Regionalization by using the deductive method of guiding } \\
\text { factors (mainly relief and geological structure; locally: soils } \\
\text { and vegetation). }\end{array}$ \\
\hline 8 & Land Use & \multirow{9}{*}{ 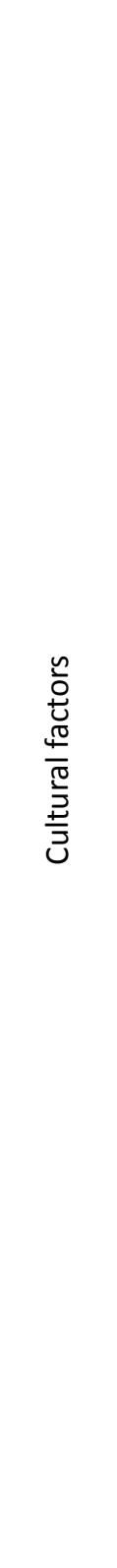 } & DoTO10k, LaBR & $\begin{array}{l}\text { The classification of developed areas was the result of the } \\
\text { generalization of LaBR and DoTO10k land use divisions. }\end{array}$ \\
\hline 9 & $\begin{array}{l}\text { Forms of Nature } \\
\text { Protection }\end{array}$ & & $\begin{array}{l}\text { NPF, DoTO10k, } \\
\text { LaBR }\end{array}$ & \\
\hline 10 & $\begin{array}{l}\text { Protection and Care } \\
\text { of the Material } \\
\text { Cultural Heritage }\end{array}$ & & $\begin{array}{l}\text { SoSDCaD, MCP, } \\
\text { MGI_25, } \\
\text { DoTO10k, LaBR }\end{array}$ & $\begin{array}{l}\text { Location of objects contained in the municipal monument } \\
\text { records based on independent geocoding of addresses of } \\
\text { buildings. Some surface separations were generalized to } \\
\text { points due to the incomplete description of their location } \\
\text { on the monument cards. }\end{array}$ \\
\hline 11 & $\begin{array}{l}\text { Spatial Development } \\
\text { of Buildings in the } \\
\text { Years 1930-2018 }\end{array}$ & & $\begin{array}{l}\text { MGI_25, } \\
\text { Topo_10_65, } \\
\text { DoTO10k, LaBR }\end{array}$ & $\begin{array}{l}\text { Archival } 1: 25,000 \text { Messtischblätt maps were not included } \\
\text { due to the considerable time heterogeneity of individual } \\
\text { sheets covering the analyzed area. }\end{array}$ \\
\hline 12 & $\begin{array}{l}\text { Change in the } \\
\text { Range of Forested } \\
\text { Areas Compared to } \\
\text { the State as of } 1930\end{array}$ & & $\begin{array}{l}\text { MGI_25, } \\
\text { Topo_10_65, } \\
\text { DoTO10k, LaBR }\end{array}$ & $\begin{array}{l}\text { Archival } 1: 25,000 \text { Messtischblätt maps were not included } \\
\text { due to the considerable time heterogeneity of individual } \\
\text { sheets covering the analyzed area. }\end{array}$ \\
\hline 13 & $\begin{array}{l}\text { WIG Maps From } \\
\text { 1930-1932 Compared } \\
\text { to Records Contained } \\
\text { in the Land Registry } \\
\text { From } 2018\end{array}$ & & MIG_25, LaBR & \\
\hline 14 & $\begin{array}{l}\text { The compactness } \\
\text { of the Shape of } \\
\text { Registration Plots }\end{array}$ & & DoTO10k, LaBR & $\begin{array}{l}\text { The Kostrubiec index was applied to analyze the compactness } \\
\text { of the shape of cadastral plots (Kostrubiec, 1972): } \\
S=\frac{\text { quadrat of perimeter of the figure }}{\text { area of the figure }}-12.56\end{array}$ \\
\hline 15 & $\begin{array}{l}\text { Development } \\
\text { Management }\end{array}$ & & $\begin{array}{l}\text { SoSDCaD, } \\
\text { DoTO10k, LaBR }\end{array}$ & $\begin{array}{l}\text { Developed areas and those intended for development in } \\
\text { SoSDCaD, as well as areas provided for by the local plan, } \\
\text { together with their dominant function, are presented. }\end{array}$ \\
\hline 16 & $\begin{array}{l}\text { Map of Cultural } \\
\text { Coverage Units }\end{array}$ & & DoTO10k, LaBR & $\begin{array}{l}\text { Additionally, the map presents compact buildings, understood } \\
\text { as a group of a minimum of five buildings, except for facilities } \\
\text { with a purely economic function, the longest distance } \\
\text { between which does not exceed } 100 \mathrm{~m} \text { (Sejm of the Republic } \\
\text { of Poland, 1995). Clusters of buildings that meet the statutory } \\
\text { criteria of compact development were separated using the } \\
\text { DBSCAN algorithm of the QGIS program. }\end{array}$ \\
\hline
\end{tabular}


Table 1. (Cont.) List of prepared auxiliary maps.

\begin{tabular}{|c|c|c|c|c|}
\hline No. & Title & $\begin{array}{l}\text { Type of } \\
\text { factors }\end{array}$ & Data source & Methods/comments \\
\hline 17 & $\begin{array}{l}\text { Visibility From } \\
\text { Roads }\end{array}$ & \multirow{3}{*}{ 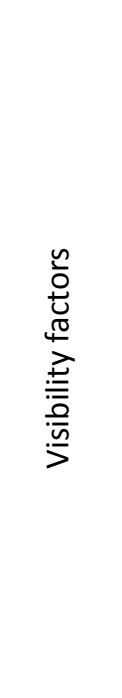 } & $\begin{array}{l}\text { DSM, DTM, } \\
\text { DoTO10k, LaBR }\end{array}$ & $\begin{array}{l}\text { Visibility range calculated using the "Visibility Analysis" plug-in of } \\
\text { QGIS-"binary viewshed" function. Adopted observation height: } \\
1.65 \mathrm{~m} \text {; analysis range: } 10 \mathrm{~km} \text {. Observation points are spaced } \\
\text { every } 50 \mathrm{~m} \text { along the roads. The analysis was conducted on a } \\
\text { modified DSM model with a spatial resolution of } 4 \mathrm{~m} \text {, from which } \\
\text { trees within a radius of } 15 \mathrm{~m} \text { from the axis of the analyzed roads } \\
\text { were excluded. }\end{array}$ \\
\hline 18 & Horizon Visibility & & $\begin{array}{l}\text { DSM, ORTHO, } \\
\text { Topo_10_65 }\end{array}$ & $\begin{array}{l}\text { Horizon visibility calculated using the "Visibility Analysis" plug-in of } \\
\text { QGIS-"horizon full" function. Adopted observation height: } 1.65 \mathrm{~m} \text {; } \\
\text { analysis range: } 10 \mathrm{~km} \text {. Observation points are spaced every } 50 \mathrm{~m} \\
\text { along the roads. The analysis was conducted on a modified NLCM } \\
\text { model with a spatial resolution of } 4 \mathrm{~m} \text {, from which trees within a } \\
\text { radius of } 15 \mathrm{~m} \text { from the axis of the analyzed roads were excluded. }\end{array}$ \\
\hline 19 & $\begin{array}{l}\text { Visibility of the } \\
\text { Church }\end{array}$ & & $\begin{array}{l}\text { DSM, ORTHO, } \\
\text { DoTO10k, LaBR }\end{array}$ & $\begin{array}{l}\text { Visibility range calculated using the "Visibility Analysis" plug-in of } \\
\text { QGIS-"binary viewshed" function, based on the DSM model with } \\
\text { a spatial resolution of } 4 \mathrm{~m} \text {. }\end{array}$ \\
\hline
\end{tabular}

Notes: Explanation of abbreviations: DoTO10k - database of topographic objects; LaBR-lands and buildings registry; NPF-nature protection forms; DSM-digital surface model with one-meter resolution generated from LiDAR data; DTM-digital terrain model with one-meter resolution generated from LiDAR data; ORTHO-orthophoto map; MCP-monument care program; DGMP50k-detailed 1:50,000 geological map of Poland; SoSDCaD—the study of spatial development conditions and directions thereof; Topo_10_651:10,000 topographic map, "1965" coordinate system; MGI25-detailed 1:25,000 map by the Military Geographic Institute.

\subsection{Field Study}

Field studies included a general assessment of the elements and features of open landscapes in terms of their visual impact. The studies mainly focused on identifying the visibility ranges in open areas from local roads and determining the views' nature. Three bicycle tourist routes running through the research area along the most critical local roads were selected for analysis. Visual features pre-recognized with a digital application have been compared to the results of field studies. Two aspects of the landscape visual perception were explored: the exposure and the composition. The former explains how the observer may see the landscape; the latter describes what can be seen by the observer. During the desk studies, sequences of viewpoints along the scenic road network were indicated, together with the areas of visible surfaces (Table 1, no. 17). The quantitative results made it possible to select the viewshed of the most significant regions or those of the maximum potential for a composition cognition. The maximum view contours were identified by horizon visibility measurement from the points on the road network (Table 1, no. 18). In this way, viewing corridors and intangible walls, noticeable while observing, could be precisely established.

During field studies, substantial, translucent, and intangible walls of the landscape enclosures were indicated, followed by view connections between them. Moreover, the nature of view openings-limited or panoramic-was determined (see Figure 4). Measuring the visibility range of dominant features leads to deter- mining significant motives of landscape composition perceivable from viewpoints or scenic routes. The church tower in the study area was considered a dominant feature, so the visibility of the church was examined (Table 1, no. 19) and then confirmed by observation from the network of roads. Spatial compositions were interpreted within the studied area under the adopted and previously described principles, such as an arrangement of planes, solids, lines, or points, and their visual features perceived from scenic routes (see Figure 5).

\section{Results}

As a result of the study, internally consistent LPUs (i.e., synthetic units with a distinctive pattern) were identified as those that stand out from the neighboring units in terms of natural and cultural features and the visual perception thereof. The reconciliation process of synthetic LPU involved comparing the nature and disposition of physical-geographical, and cultural attributes with their visual features (Ode et al., 2008). This process was intended to obtain the greatest possible internal uniformity and coherence in terms of the material structure and spatial composition. In debatable cases, the final path of the boundaries was determined by following the guideline of the area perception as a visual whole. The identified LPUs are mapped in Figure 6 and listed in Table 2 (see column 3A in Table 2). They refer to the physical-geographical mesoregions designated in Poland according to the regionalization developed by Solon et al. (2018; see column 1 in Table 2) and with regards to the 


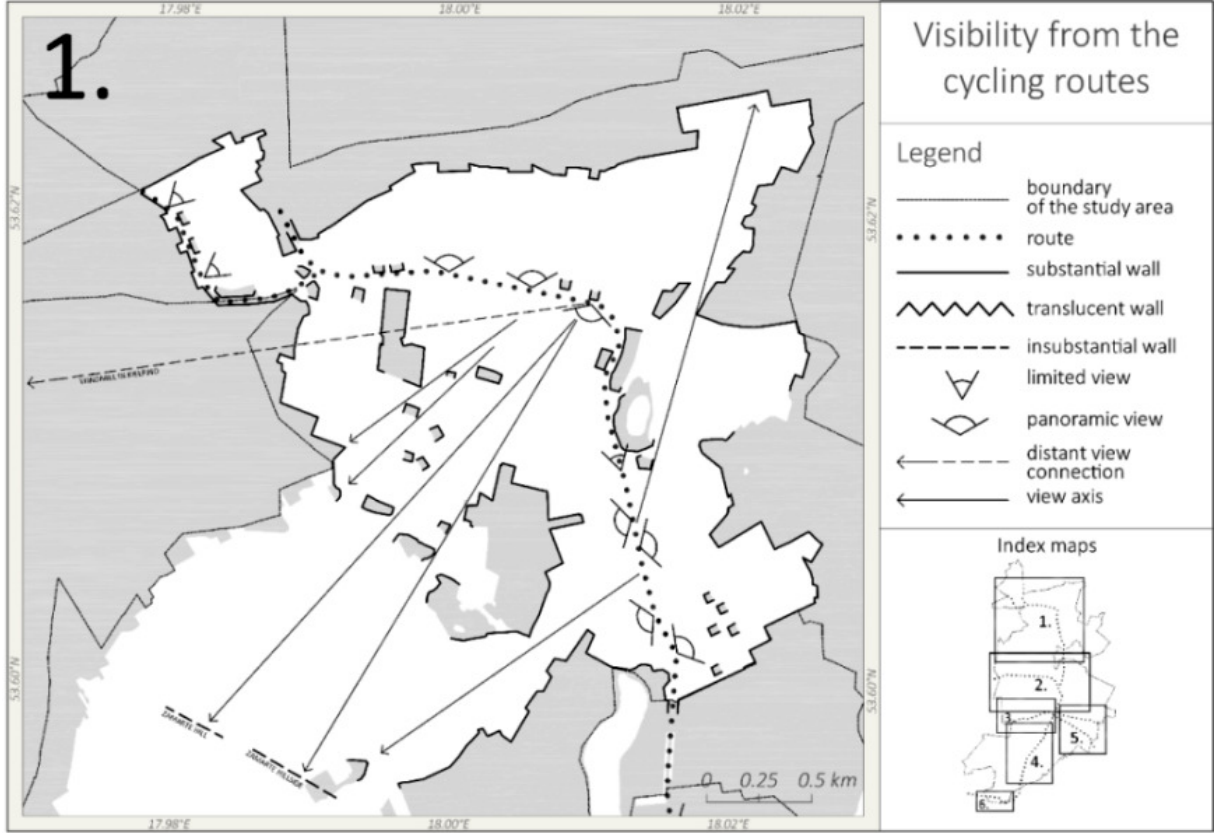

Figure 4. Analysis of landscape exposure of route 1 and characteristics of the limited fields of view.

landscape subtypes adopted in Poland (see columns 2A and $2 \mathrm{~B}$ in Table 2). The forms of relief and the interconnected nature of land cover within identified LPUs are described in columns $3 \mathrm{~B}$ and $3 \mathrm{C}$ of Table 2. Each LPU has a proper name assigned along with a description aligned with the numeric list (e.g., H8-Cekcynek Hill). Its first part refers to toponymy and identity and represents the cultural landscape features, while the second part defines topographic features and represents the natural landscape. Both indicate the perception of the place.

A rural landscape dominates the majority of the studied area with a mosaic of small fields. It has the form of a large forest clearing for settlement purposes. The area almost entirely coincides with the range of the undu- lating moraine upland classified as the Świecie Upland. This part of the studied area includes 10 separate units located on hills and three plain landscape units that lie partly within its boundaries. In the case of the Ostrowo Depression, its north-western edge remains the only part that interferes with the studied zone. The area includes 12 narrow and relatively shallow valleys, usually covered with meadows and bushes, ranging from the northeast to the southwest. These are short sections of water-free, post-lakes channels, or melt channels. The western, northern, and eastern ends within the study's boundaries also include numerous fragments of plains and depressions, mostly forested ones assigned to the mesoregions of the Tuchola Forest and Brda Valley.

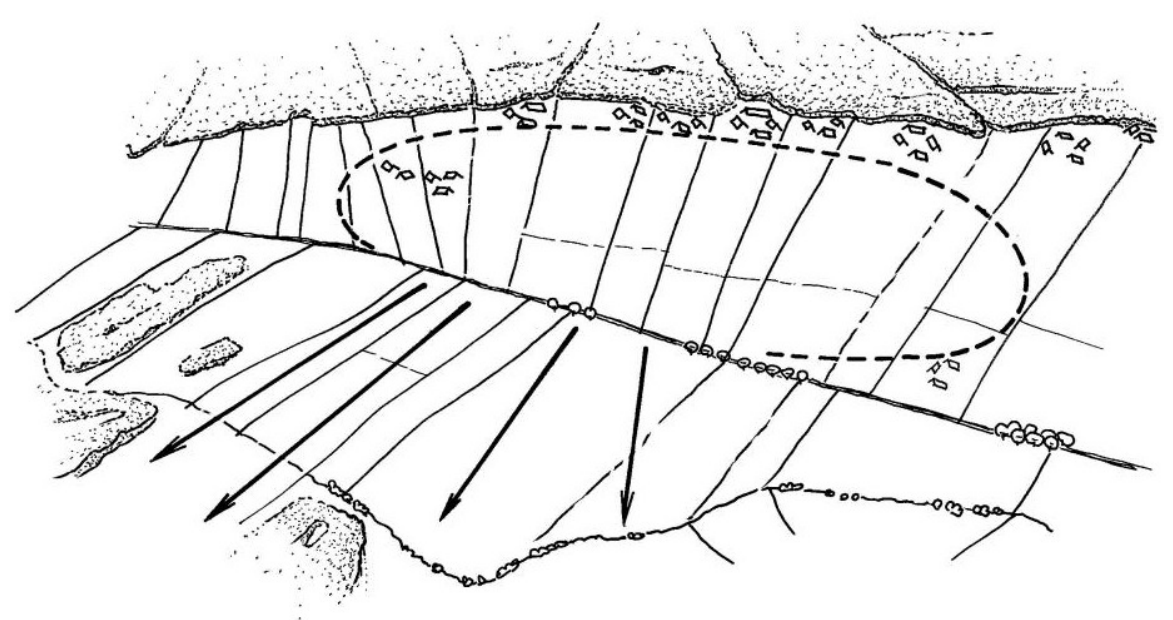

Figure 5. A synthetic sketch of the spatial composition for the sequence of views from route 1 . The northern side of the route: a completely uncovered, slightly rising field with radial bounds, enclosed by the forest, and a few buildings; the southern side of the route: a panoramic view of the undulating terrain with irregular fields and distant forests. 


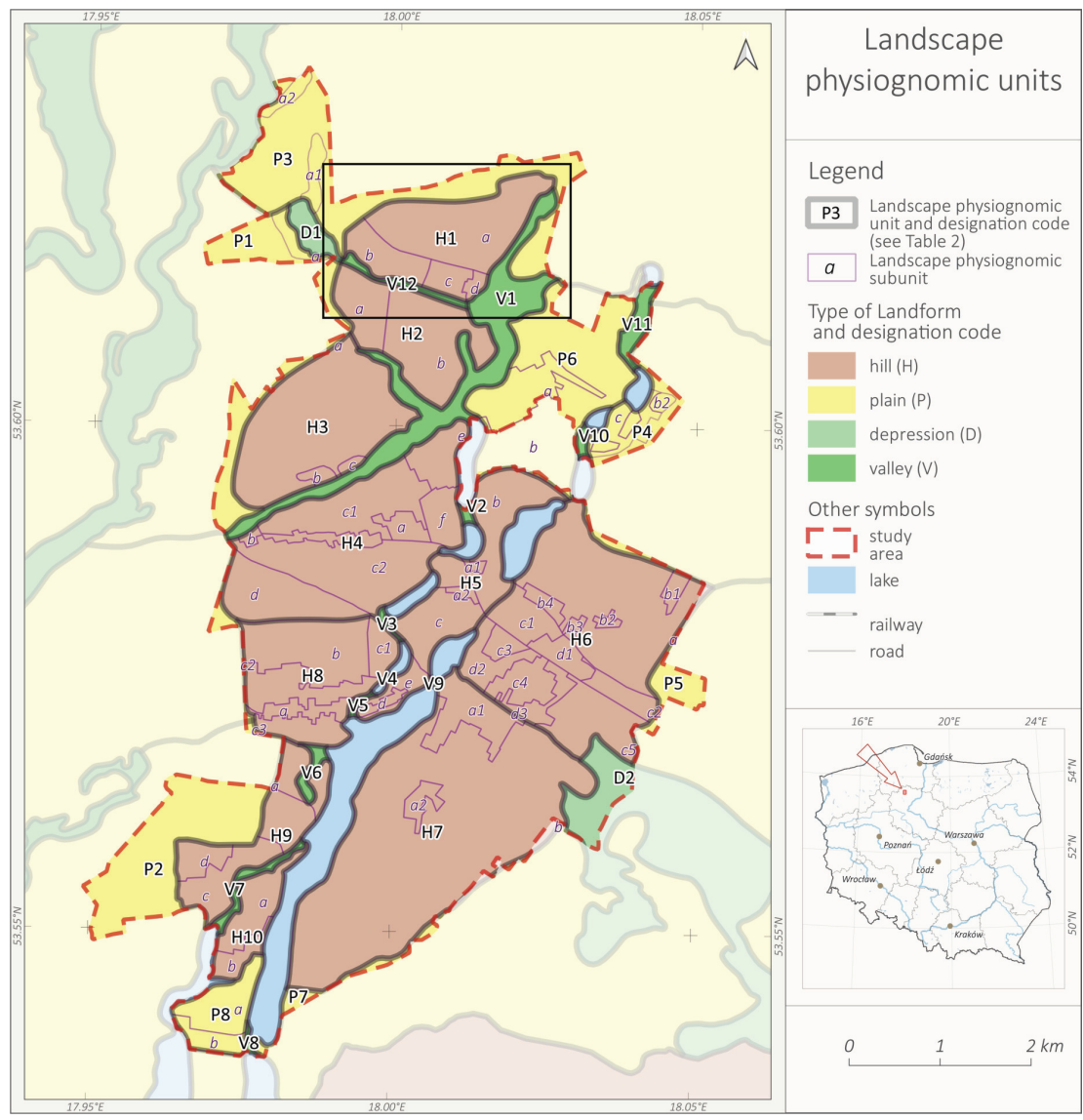

Figure 6. LPUs and subunits. The area selected for a detailed description (marked with the rectangle).

Table 2. Classification of the landscape units of the study area with integrated description of subunits.

\begin{tabular}{|c|c|c|c|c|c|c|}
\hline \multirow[t]{3}{*}{ 1. Regional context } & \multicolumn{2}{|c|}{ 2. Subregional context } & \multicolumn{4}{|c|}{ 3. Local context } \\
\hline & & & \multicolumn{4}{|l|}{ LPU } \\
\hline & $2 \mathrm{~A}$ & $2 \mathrm{~B}$ & $3 A$ & $3 B$ & $3 C-3 E$ & \\
\hline \multirow{5}{*}{$\begin{array}{l}\text { Brda Valley } \\
\text { Landscapes } \\
314.72 \\
\text { (Solon et al., } \\
\text { 2018) }\end{array}$} & \multirow[t]{4}{*}{ Plains } & \multirow{5}{*}{ 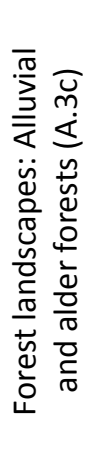 } & \multirow[t]{2}{*}{ P1 Okiersk } & \multirow[t]{2}{*}{$\begin{array}{l}\text { Undulating } \\
\text { plain }\end{array}$} & $\begin{array}{l}\text { a. Compact village building } \\
\text { development }\end{array}$ & \\
\hline & & & & & $\begin{array}{l}\text { b. Forests: New coniferous } \\
\text { forest }\end{array}$ & $\begin{array}{l}1 \\
2 \\
3 \\
4\end{array}$ \\
\hline & & & \multirow[t]{2}{*}{ P2 Płazy } & \multirow[t]{2}{*}{$\begin{array}{l}\text { Undulating } \\
\text { plain }\end{array}$} & $\begin{array}{l}\text { a. Mid-forest field with compact } \\
\text { buildings and bushes }\end{array}$ & \\
\hline & & & & & b. Forest perforated with glades & \\
\hline & Depressions & & D1 Okiersk & Flat plain & Mosaic of meadows, fields, and & ees \\
\hline
\end{tabular}


Table 2. (Cont.) Classification of the landscape units of the study area with integrated description of subunits.

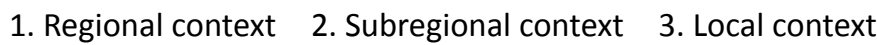

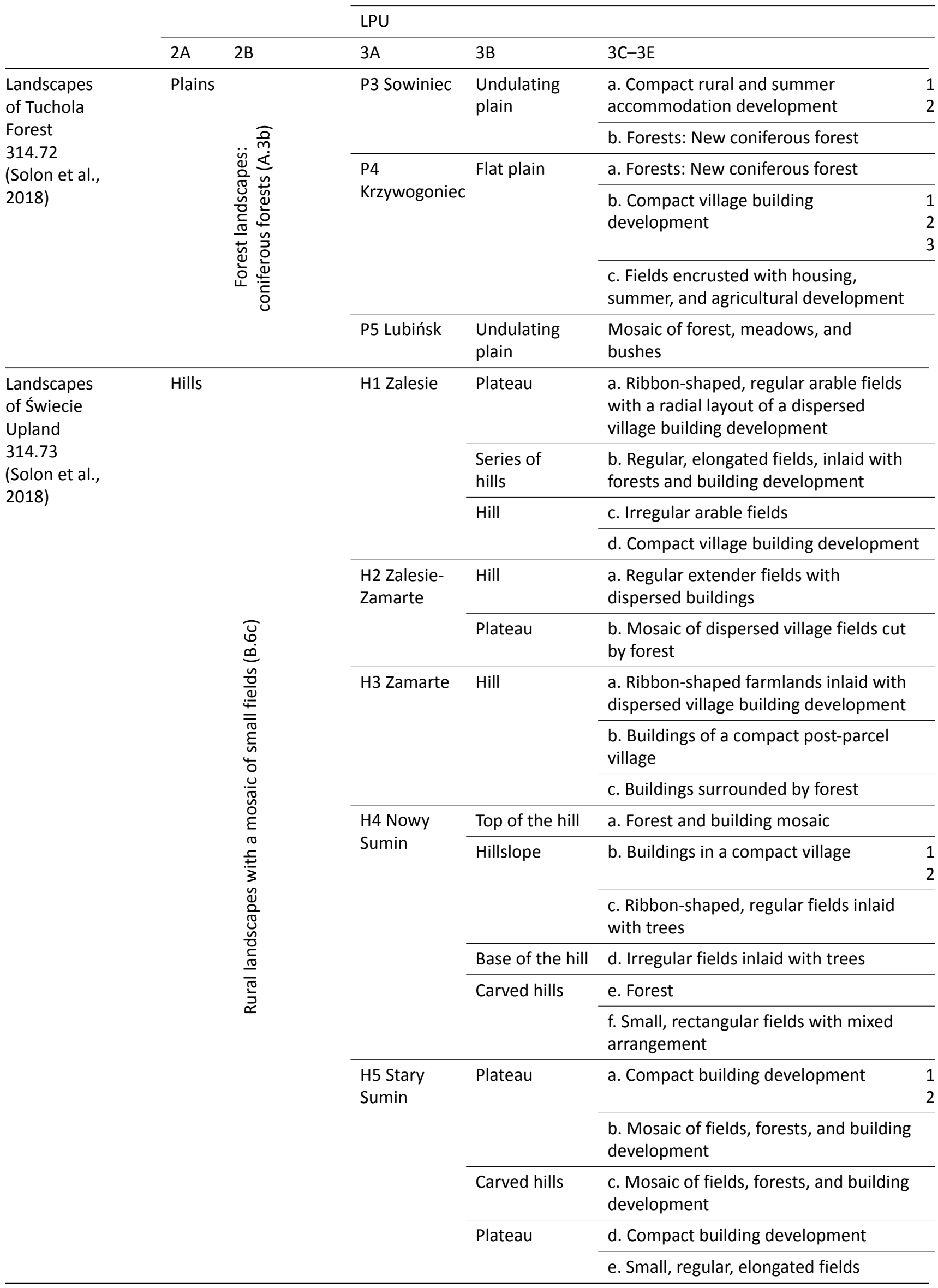


Table 2. (Cont.) Classification of the landscape units of the study area with integrated description of subunits.

1. Regional context $\quad 2$. Subregional context $\quad 3$. Local context

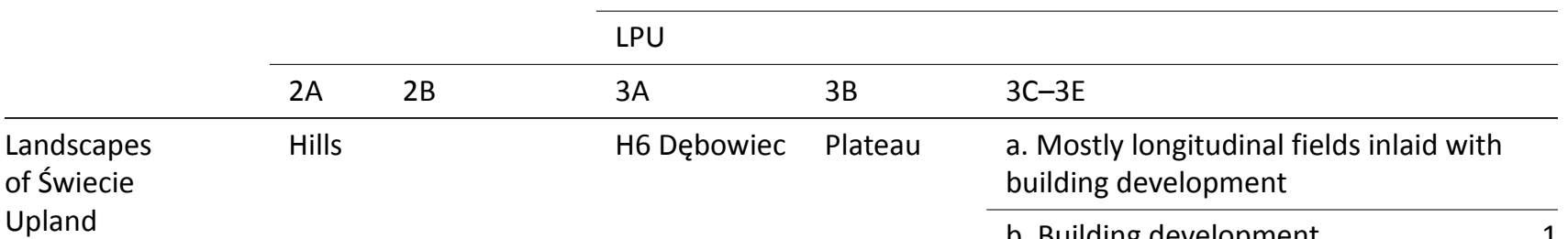

314.73

b. Building development 1

(Solon et al.,

2018)

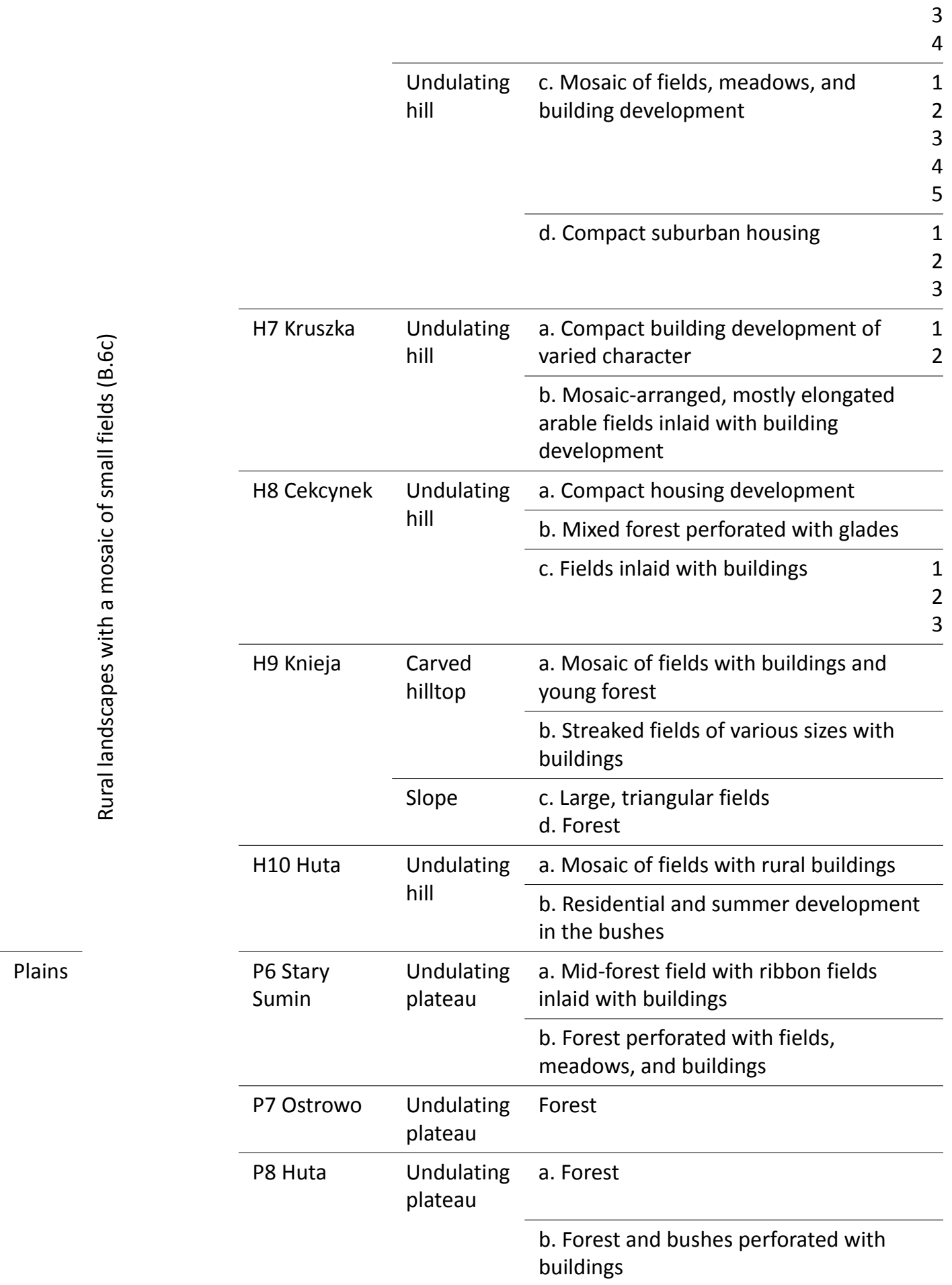


Table 2. (Cont.) Classification of the landscape units of the study area with integrated description of subunits.

\begin{tabular}{|c|c|c|c|c|c|}
\hline \multirow[t]{3}{*}{ 1. Regional context } & \multirow{2}{*}{\multicolumn{2}{|c|}{ 2. Subregional context }} & \multicolumn{3}{|l|}{ 3. Local context } \\
\hline & & & \multicolumn{3}{|l|}{ LPU } \\
\hline & $2 \mathrm{~A}$ & $2 B$ & $3 A$ & 3B & $3 C-3 E$ \\
\hline \multirow{15}{*}{$\begin{array}{l}\text { Landscapes } \\
\text { of Świecie } \\
\text { Upland } \\
314.73 \\
\text { (Solon et al., } \\
2018 \text { ) }\end{array}$} & \multirow[t]{14}{*}{ Valleys } & \multirow{14}{*}{ 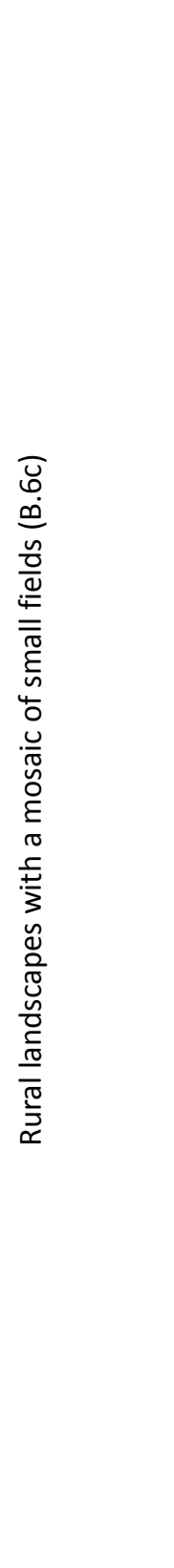 } & V1 Rakówka & \multirow{13}{*}{$\begin{array}{l}\text { Water- } \\
\text { free, } \\
\text { post-lake } \\
\text { channels }\end{array}$} & \multirow[t]{6}{*}{ Mowed meadows } \\
\hline & & & $\begin{array}{l}\text { V2 Lakes } \\
\text { Mętne and } \\
\text { Zadworne }\end{array}$ & & \\
\hline & & & V3 Lakes & & \\
\hline & & & Chłodne and & & \\
\hline & & & & & \\
\hline & & & $\begin{array}{l}\text { V4 Lakes } \\
\text { Wielkie Skąpe } \\
\text { and Małe } \\
\text { Skąpe }\end{array}$ & & \\
\hline & & & $\begin{array}{l}\text { V5 Lakes Małe } \\
\text { Skąpe and } \\
\text { Cekcyńskie }\end{array}$ & & Mowed meadows and fields \\
\hline & & & $\begin{array}{l}\text { V6 Lake } \\
\text { Cekcyńskie }\end{array}$ & & Overgrown meadow \\
\hline & & & $\begin{array}{l}\text { V7 Lakes } \\
\text { Cekcyńskie } \\
\text { and Miały }\end{array}$ & & $\begin{array}{l}\text { Mowed and unmowed meadows } \\
\text { and bushes }\end{array}$ \\
\hline & & & $\begin{array}{l}\text { V8 Lakes } \\
\text { Cekcyńskie } \\
\text { and } \\
\text { Drzycimskie }\end{array}$ & & Mowed meadows and fields \\
\hline & & & $\begin{array}{l}\text { V9 Lakes } \\
\text { Główka and } \\
\text { Cekcyńskie }\end{array}$ & & $\begin{array}{l}\text { Mosaic of buildings, meadows, } \\
\text { trees, and bushes }\end{array}$ \\
\hline & & & $\begin{array}{l}\text { V10 Lakes } \\
\text { Wołyczek and } \\
\text { Okoninek }\end{array}$ & & $\begin{array}{l}\text { Mowed and unmowed meadows } \\
\text { and bushes }\end{array}$ \\
\hline & & & $\begin{array}{l}\text { V11 Lakes } \\
\text { Szczuczanek } \\
\text { and } \\
\text { Krzywogoniec }\end{array}$ & & $\begin{array}{l}\text { Mosaic of mowed meadows, fields, } \\
\text { and trees }\end{array}$ \\
\hline & & & V12 Zalesie & $\begin{array}{l}\text { Meltwater } \\
\text { valley }\end{array}$ & Mowed meadows, fields, and trees \\
\hline & Depressions & 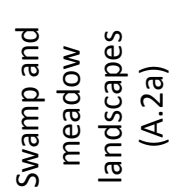 & D2 Ostrowo & Flat plain & $\begin{array}{l}\text { Mosaic of meadows, fields, and } \\
\text { trees }\end{array}$ \\
\hline
\end{tabular}

The columns $3 \mathrm{C}-3 \mathrm{E}$ in Table 2 contain a combined description of cultural characteristics and perceptions. A further breakdown of LPUs into subunits where visual perception can be described is shown in Figure 7 and Table 3. In Table 3, the part relating to selected LPUs is expanded to four columns-3B, 3C, 3D, and $3 E-$ which described, respectively, relief, land use, exposure, and composition.

It was assumed that the LPUs identification and classification aims to support spatial planning and land management, preserving the beauty, or restoring landscapes degraded by urban sprawl. The topography of lakes 


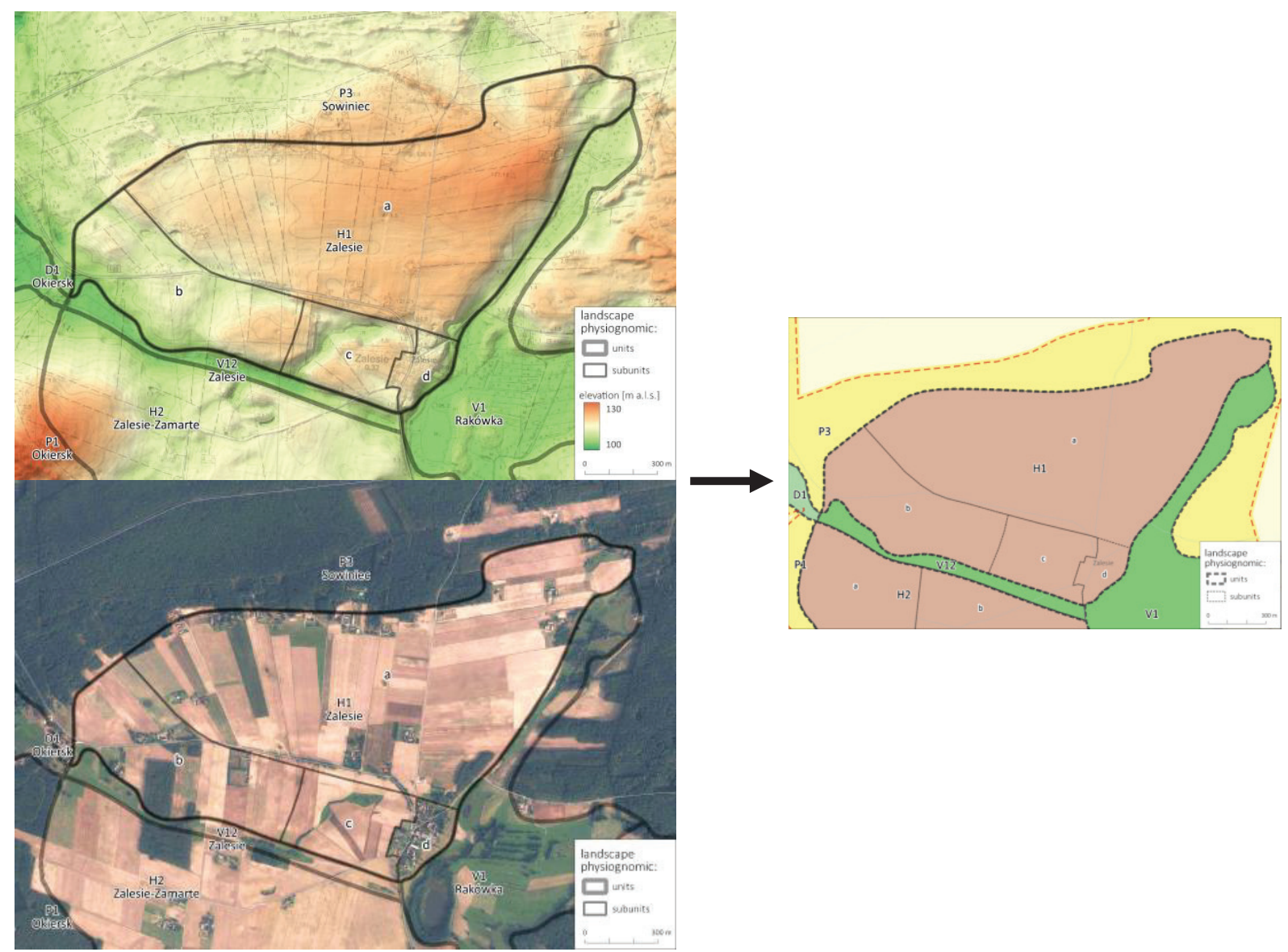

Figure 7. The subdivision of selected LPUs based on the relief and arrangement of land cover characteristics (orthophoto map).

seems essential, i.e., for the picturesqueness of the area, but to a lesser extent for building development. These areas are included in LPUs classification only indirectly. Therefore, they have not been listed in Table 2. However, the perception of lakes can still be explored from scenic land points.

\section{Discussion and Conclusions}

Many methods of identifying and classifying landscapes exist and serve a variety of purposes. Three main research approaches may be distinguished that differ in objectivism-subjectivism (Simensen et al., 2018).

Table 3. Extension of Table 2 regarding the description of landscape exposure and composition.

\begin{tabular}{|c|c|c|c|c|c|}
\hline \multirow{2}{*}{ LPU 3A } & \multicolumn{5}{|c|}{ Visual Perception } \\
\hline & Relief 3B & Land use 3C & & Exposure 3D & Composition 3E \\
\hline \multirow{4}{*}{$\begin{array}{c}\mathrm{H} 1 \\
\text { Zalesie }\end{array}$} & Plateau & $\begin{array}{l}\text { a. Arable fields with a village } \\
\text { building development }\end{array}$ & \multirow{3}{*}{ 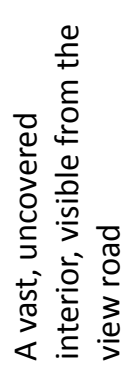 } & $\begin{array}{l}\text { View plan enclosed } \\
\text { by a forest wall inlaid } \\
\text { with buildings }\end{array}$ & $\begin{array}{l}\text { Ribbon-shaped, regular arable } \\
\text { fields with a radial layout } \\
\text { of dispersed farm buildings }\end{array}$ \\
\hline & $\begin{array}{l}\text { Series } \\
\text { of hills }\end{array}$ & $\begin{array}{l}\text { b. Arable fields with forests } \\
\text { and building development }\end{array}$ & & Open view plan & $\begin{array}{l}\text { Regular, elongated fields, } \\
\text { inlaid with forests and } \\
\text { farm buildings }\end{array}$ \\
\hline & \multirow[t]{2}{*}{ Hill } & c. Arable fields & & $\begin{array}{l}\text { View plan enclosed by } \\
\text { building development }\end{array}$ & Irregular arable fields \\
\hline & & $\begin{array}{l}\text { d. Village building } \\
\text { development }\end{array}$ & \multicolumn{2}{|c|}{$\begin{array}{l}\text { Village buildings exposed from } \\
\text { the view road and the } \\
\text { surrounding fields }\end{array}$} & $\begin{array}{l}\text { One-story, traditional } \\
\text { farmhouses loosely situated } \\
\text { with an extended front to a } \\
\text { village road, farms at the back }\end{array}$ \\
\hline
\end{tabular}


The first approach is of a subjective, intuitive, and interpretive nature. It explores holistic landscape concepts by analyzing aesthetic, natural, and cultural landscape features together. This approach is represented by Landscape Character Assessment in United Kingdom (Fairclough et al., 2018; Julie Martin Associates \& Swanwick, 2003; Swanwick, 2002) and various studies, e.g., in Spain (Nogué et al., 2016), Hungary (Boromisza et al., 2011), or Poland (Solecka et al., 2018). The second approach is to describe the landscape based on natural or cultural factors, which are preselected depending on the specifics of a scientific discipline. In Poland, this group of methods is represented by Solon et al. (2018) or Krajewski (2011). However, the third approach is multivariate and involves mapping a range of statistical biophysical data (Cushman et al., 2010, pp. 83-108).

The proposed procedure adopts the characterization process in the landscape character assessment methodology (Scottish Natural Heritage Tayside and Clackmannan Area Office, 2001; Swanwick, 2002; Swanwick \& Fairclough, 2018, pp. 21-36). Its holistic perspective assumes that the character of a landscape depends on the interaction between the physical features of the area, as well as the process of perception and decision-making (Daniel, 2001). The method of landscape characterization includes associations or memories. It is, thus, interpretative in nature, yet the results are difficult to replicate. Many similar procedures exist that apply the landscape character assessment methodology. Some of them are for expert-used only, while other ones may be participatory. Some still combine the previous approaches. Participation is beneficial, both in the assessment stage and in the judgment phase, if applicable, because negotiations prevent conflicts.

In the conducted study, a methodology for identifying LPUs has been developed and tested in a part of the Cekcyn municipality, Poland. Internally, coherent areas have been identified. They are relatively homogeneous in terms of physical-geographical, cultural, and visual features. The same principles of land management and development could be applied within them. It was considered crucial to identify a spatial pattern that people can read and imitate while shaping, planning, or managing space to protect the landscape (Bell, 2012).

The results obtained address the issues of space management in Poland, manifested by excessive dispersion of building development in rural areas, and its destructive effects on the variety and beauty of the landscape (Chmielewski et al., 2018a, 2018b; Kowalewski et al., 2013; Wilkin \& Nurzyńska, 2018). Implementation of the ELC principles is regulated in Poland by the Act Amending Certain Acts in Connection with the Strengthening of Landscape Protection Tools (Sejm of the Republic of Poland, 2015), which launched the landscape audit procedure in 2019. The physiognomy examination method applied in the audit needs to be developed. Simultaneously, the landscape research conducted at Poland's local or place level fails to provide suffi- cient knowledge and data. The theory and tradition of landscape studies in physical geography and landscape architecture or landscape ecology remain disintegrated. For these reasons, the described above process of characterization of landscape physiognomy is aimed in the right direction. The national conditionings for the novelty of the results obtained consist in:

- Hierarchical division of landscapes to be completed at a local level, where each distinguished area represents a specific type of landscape and could be further subdivided (O'Neil et al., 1991; Swanwick, 2002);

- Recognition of the spatial pattern that represents natural, cultural, and perceptual landscape characteristics in an integrated manner;

- Entering the recognized pattern into a hierarchical and continuous landscape system.

The advantages of the LPU methodology for spatial planning may be as follows:

- Systematization of knowledge of landscape characteristics;

- Identification of landscape shaping conditions on various planning levels;

- Landscape beauty protection by imitation or restoration of the recognized spatial pattern.

Two findings confirm the ordering function of the LPU identification method. The results indicate a significant discrepancy between the zone planned in SoSDCaD and integral LPUs in the studied area. This result suggests that the method described helps identify more integral land planning zones and define management principles thereof in a more appropriate way. Moreover, the boundaries of the physical-geographical mesoregions under the classification by Solon et al. (2018) partially run through the middle of homogeneous LPUs determined during the study. The two areas prove overly divergent in the directional course in some parts, though this may also be associated with a difference in scales.

The method's limitations result from the lack of comprehensive knowledge and spatial data on cultural, historical, and natural characteristics in rural areas at the local level. A lack of data on monuments and types of plant communities has been indicated. Moreover, the adopted research area was not sufficient to fully standardize the landscapes' description. Therefore, further testing of the method in more diverse areas is needed. The general weakness of LPUs method, which paradoxically may also be seen as a strength in land use planning, results from its holistic assumptions. This refers to certain intuitiveness of spatial patterns and units or subunits boundaries. Possible conflict in planning decisionmaking can be minimized by participation included in the procedure in the future. However, it can already be concluded at this study stage that the identification 
procedure of LPUs may help implement the ELC assumptions regarding the formation of sustainable landscapes, protection, planning, and management thereof, as well as gathering knowledge on natural, cultural, and visual features of the landscape.

\section{Acknowledgments}

We thank the Faculty of Architecture of the Gdańsk University of Technology for the funds provided. We also thank the Cekcyn authorities for facilitating the field studies and the information survey.

\section{Conflict of Interests}

The authors declare no conflict of interests.

\section{References}

Antrop, M. (2000). Background concept for integrated landscape analysis. Agriculture, Ecosystem and Environment, 77(1/2), 17-28. https://doi.org/10.1016/ S0167-8809(99)00089-4

Antunes, P., Kallis, G., Videira, N., \& Santos, R. (2009). Participation and evaluation for sustainable river basin governance. Ecological Economics, 68(4), 931-939. https://doi.org/10.1016/j.ecolecon.2008.12.004

Appleyard, D., Lynch, K., \& Meyer, J. R. (1964). The view from the road (1st ed.). MIT Press.

Bell, S. (2012). Landscape: Pattern, perception, and process (2nd ed.). Routledge.

Bishop, K., \& Phillips, A. (Eds.). (2012). Countryside Planning: New approaches to management and conservation. Routledge.

Bogdanowski, J. (1976). Kompozycja i planowanie w architekturze krajobrazu [Composition and planning in landscape architecture] (1st ed.). Zakład Narodowy im.Ossolińskich.

Bogdanowski, J. (1999). Metoda jednostek i wnętrz architektoniczno-krajobrazowych $w$ studiach $i$ projektowaniu [The architectural and landscape units and rooms method in studies and design] (4th ed.). Wydawnictwo Politechniki Krakowskiej.

Bogdanowski, J., Łuczyńska-Bruzda, M., \& Novák, Z. (1981). Architektura krajobrazu [Landscape architecture] (2nd ed.). PWN.

Böhm, A. (2016). O czynniku kompozycji w planowaniu przestrzennym [About composition factor in space planning] (2nd ed.). Wydawnictwo Politechniki Krakowskiej.

Boromisza, Z., Csima, P., Dublinszki-Boda, B., \& Módosné Bugyi, I. (2011). Landscape character assessment methodology applied for specific landscape types in Hungary. The Problems of Landscape Ecology, 30, 233-239.

Cekcyn Municipality Council. (2018). Studium uwarunkowań i kierunków zagospodarowania przestrzennego gminy Cekcyn [Study of spatial development con- ditions and directions for CekcynCounty/SoSDCaD] (XXXV/328/18). Unpublished document.

Cherrie, T. (Ed.). (2007). Visual landscape planning in Western Australia. A manual for evaluation, assessment, siting and design. Western Australian Planning Commission.

Chmielewski, T. J., Butler, A., Kułak, A., \& Chmielewski, S. Z. (2017). Landscape's physiognomic structure: Conceptual development and practical applications. Landscape Research, 43, 410-427. https://doi.org/ 10.1080/01426397.2017.1314454

Chmielewski, T. J., Chmielewski, S. Z., \& Kułak, A. (2019). Percepcja i projekcja krajobrazu: Teorie, zastosowania, oczekiwania [Perception and projection of the landscape: Theories, applications, expectations]. Przeglaqd Geograficzny, 9(3), 365-384.

Chmielewski, T. J., Michalik-Śnieżek, M., \& Kułak, A. (2014). Klasyfikacja stopnia antropogenicznego przekształcenia krajobrazu i jej zastosowanie w planie ochrony Poleskiego Parku Narodowego [Classification of the degree of anthropogenic landscape transformation and its application in the protection plan of Poleski National Park]. Problemy Ekologii Krajobrazu, 38, 107-124.

Chmielewski, T. J., Myga-Piątek, U., \& Solon, J. (2015). Typologia aktualnych krajobrazów Polski [Typology of current Polish landscapes]. Przegląd Geograficzny, 87(3), 377-408.

Chmielewski, T. J., Śleszyński, P., Chmielewski, S. Z., \& Kułak, A. (2018a). Estetyczne koszty chaosu przestrzennego [Aesthetic costs of spatial chaos]. Studies of the Spatial Development Committee of the Country Polish Academy of Sciences, 182(2), 365-403.

Chmielewski, T. J., Śleszyński, P., Chmielewski, S. Z., \& Kułak, A. (Eds.). (2018b). Ekologiczne i fizjonomiczne koszty bezładu przestrzennego [Ecological and physiognomic costs of spatial chaos] [Special Issue]. Prace Geograficzne, 264.

Cullen, G. (1961). The concise townscape. Architectural Press.

Cushman, S. A., Gutzweiler, K., Evans, J. S., \& McGariga, K. (2010). The gradient paradigm: A conceptual and analytical framework for landscape ecology. In S. A. Cushman \& F. Huettmann (Eds.), Spatial complexity, informatics, and wildlife conservation (pp. 83-108). Springer.

Daniel, T. (2001). Whither scenic beauty? Visual landscape quality assessment in the 21th century. Landscape and Urban Planning, 54, 267-281.

Fairclough, G., Sarlöv Herlin, I., \& Swanwick, C. (Eds.). (2018). Handbook of landscape character assessment. Current approaches to characterisation (1st ed.). Routledge.

Fairhurst, K. (2004). Visual landscape system for planning and managing aesthetic resource (Report No. 1023050, Cumulative Environmental Management Associations). Unpublished document. https://img1. 
wsimg.com/blobby/go/f10227fa-b955-42b0-a3fbb2475325bb90/downloads/FairhurstVisuaL landscapeSystemforPlanningandMa.pdf? ver $=1619473067909$

Forczek-Brataniec, U. (2008). Widok z drogi. Krajobraz $w$ percepcji dynamicznej [The view from the road. Landscape in dynamic perception] (1st ed.). Alamed Media Group.

Forczek-Brataniec, U. (2018). Przestrzeń widziana. Analiza widokowa $w$ planowaniu i projektowaniu [Visual space. Visual analysis in landscape planning and design] (1st ed.). Wydawnictwo Politechniki Krakowskiej.

Julie Martin Associates, \& Swanwick, C. (2003). Overview of Scotland's national programme of landscape character assessment (Report No. F03 AA307). Scottish National Heritage. www.snh.org.uk/pdfs/ publications/commissioned_reports/f03aa.pdf

Kaplan, R., Kaplan, S., \& Ryan, R. L. (1998). With people in mind. Design and management of everyday nature (1st ed.). Island Press.

Kostrubiec, B. (1972). Analiza zjawisk koncentracji w sieci osadniczej: Problemy metodyczne [Analysis of concentration phenomena in a settlement network: Methodical problems]. Prace Geograficzne, 93, 1-114.

Kowalewski, A., Mordasewicz, J., Osiatyński, J., Regulski, J., Stępień, J., \& Śleszyński, P. (2013). Raport o ekonomicznych stratach $i$ społecznych kosztach niekontrolowanej urbanizacji w Polsce [Report about economic losses and social costs of uncontrolled urbanization in Poland] (Working paper on manuscript rights 1st version). Institute of Geography and Spatial Organization Polish Academy of Science, Foundation for the Development of Local Democracy. http:// odpowiedzialnybiznes.pl/wp-content/uploads/ 2014/07/Raport-Ekonomiczny-29.10.2013calosc.pdf

Krajewski, P. (2011). Spatial distribution of land cover of Sobótka municipality in the context of landscape capacity assessment. Problemy Ekologii Krajobrazu, 31, 81-88.

Litton, R. B., Jr., \& Tetlow, R. J. (1978). A landscape inventory framework: Scenic analysis of the Northern Great Plain. Research paper of pacific southwest forest and range experiment station. US Department of Agriculture.

Myczkowski, Z., Dyba, O., Kołodziejski, S., Leberschek, J., Marcinek, R., Siwek, A., Śledzikowski, T., \& Zacny, F. (1998). Ochrona wartości krajobrazu i środowiska kulturowego w stadium do planu i miejscowym planie zagospodarowania przestrzennego [The protection of values of cultural landscape and environment to be included in the management plan and local development plan of a commune]. Studia i Materiały. Krajobrazy, 18(30).

Natural England, \& Department for Environment, Food \& Rural Affairs. (2014). Landscape and seascape character assessments. GOV.UK. https://www.gov. uk/guidance/landscape-and-seascape-characterassessments\#landscape-character-assessments-Icas

Nogué, J., Sala, P., \& Grau, J. (2016). The landscape catalogues of Catalonia. Methodology. Landscape Observatory of Catalonia.

Novák, Z. (1997). Planowanie regionalne $i$ udział w nim architekta [Regional planning and the architect's participation in it]. Wydawnictwo Politechniki Krakowskiej. (Original work published 1950)

O’Neil, R. V., Turner, S. J., Cullinan, V. I., Coffin, D. P., Cook, T., Conley, W., Brunt, J., Thomas, J. M., Conley, M. R., \& Gosz, J. (1991). Multiple landscape scales: An intersite comparison. Landscape Ecology, 5(3), 137-144.

Ode, A., Tveit, M., \& Fry, G. (2008). Capturing landscape visual character using indicators: Touching base with landscape aesthetic theory. Landscape Research, 33(1), 89-117. https://doi.org/10.1080/ 01426390701773854

Özesmi, U., \& Özesmi, S. L. (2004). Ecological models based on people's knowledge: A multi-step fuzzy cognitive mapping approach. Ecological Modeling, 176(1), 43-64. https://doi.org/10.1016/j.ecolmodel. 2003.10.027

Richling, A., \& Ostaszewska, K. (2005). Geografia fizyczna Polski [Physical geography of Poland] (1st ed.). PWN.

Scottish Natural Heritage Tayside and Clackmannan Area Office. (2001). Perth landscape capacity study (Commissioned Report No. F99LH24A). https://www. nature.scot/snh-commissionedreport-f99lh24aperth-landscape-capacity-study

Sejm of the Republic of Poland. (1995). Ustawa o ochronie gruntów rolnych I leśnych [Act on protection of agricultural and forest land] (Item 78).

Sejm of the Republic of Poland. (2015). Ustawa o zmianie niektórych ustaw w zwiqzku ze wzmocnieniem narzędzi ochrony krajobrazu [Act amending certain acts in connection with the strengthening of landscape protection tools act] (Item 774).

Simensen, T., Halvorsena, R., \& Erikstada, L. (2018). Methods for landscape characterisation and mapping: A systematic review. Land Use Policy, 75, 557-569. https://doi.org/10.1016/j.landusepol. 2018.04.022

Smardon, R. C., Palmer, J. F., \& Felleman, J. P. (Eds.). (1986). Foundation for visual project analysis (1st ed.). Wiley.

Solecka, I., Raszka, B., \& Krajewski, P. (2018). Landscape analysis for sustainable land use policy: A case study in the municipality of Popielów, Poland. Land Use Policy, 75, 116-126. https://doi.org/10.1016/ j.landusepol.2018.01.021

Solon, J., Borzyszkowski, J., Bidłasik, M., Richling, A., Badora, K., Balon, J., Brzezińska-Wójcik, T., Chabudziński, Ł., Dobrowolski, R., Grzegorczyk, I., Jodłowski, M., Kistowski, M., Kot, R., Krąż, P., Lechnio, J., Macias, A., Majchrowska, A., Malinowska, E., Migoń, P., . . . 
Ziaja, W. (2018). Physico-geographical mesoregions of Poland: Verification and adjustment of boundaries on the basis of contemporary spatial data. Geographia Polonica, 91(2), 143-170.

Sowińska, E., \& Chmielewski, T. (2008). Metoda delimitacji i analiza typologicznego zróżnicowania jednostek przyrodniczo-krajobrazowych Roztocza i Równiny Biłgorajskiej [The method of delimitation and the analysis of typological diversity of nature-Landscape units in Roztocze and Biłgoraj Plain Regions]. Problemy Ekologii Krajobrazu, 21(2), 144-161.

Swanwick, C. (2002). Landscape character assessment: Guidance for England and Scotland. Countryside Agency and Scottish Natural Heritage.

Swanwick, C., \& Fairclough, G. (2018). Landscape character: Experience from Britain. In G. Fairclough, J. Sarlöv Herlin, \& C. Swanwick (Eds.), Routledge handbook of landscape character assessment. Current approaches to characterisation and assess- ment (1st ed., pp. 21-36). Routledge. https://www. taylorfrancis.com/books/e/9781315753423

Tetlow, R. J., \& Sheppard, S. R. J. (1979). Visual unit analysis: A descriptive approach to landscape assessment. In G. H. Elsner \& R. C. Smardon (Eds.), Proceedings of our national landscape: A conference on applied techniques for analysis and management of the visual resource (pp. 117-124). Pacific Southwest Forest and Range Experiment Station, Forest Service, US Department of Agriculture.

Tudor, C. (2014). An approach to landscape character assessment. Natural England.

Wascher, D. (Ed.). (2005). European landscape character areas. Typologies, cartography and indicators for the assessment of sustainable landscapes (Report No. 1254). Landscape Europe, ECLAI.

Wilkin, J., \& Nurzyńska, I. (Eds.). (2018). Polska wieś 2018. Raport o kondycji wsi [Polish countryside 2018. The report on countryside condition]. Wydawnictwo Naukowe Scholar.

\section{About the Authors}

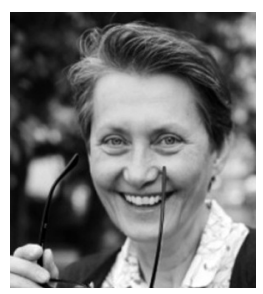

Anna Górka is an assistant professor at the Department of Sustainable Design, Faculty of Architecture, at the Gdańsk University of Technology, Poland. Her research examines regional architecture, urban design, and rural areas design and visual assessment of landscape character. Górka holds a Master of Architecture and $\mathrm{a}$ PhD and post-PhD in Architecture and Urban Planning from the Gdańsk University of Technology.

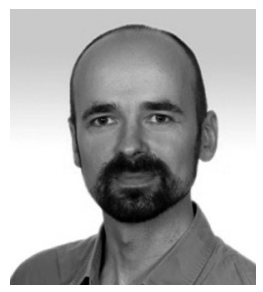

Kazimierz Niecikowski (MSc in Geography) is a research and teaching assistant at the Department of Landscape Research and Environmental Management, at the Faculty of Oceanography and Geography of the University of Gdańsk, Poland. His main area of research is GIS-based methods for landscape analysis. 